\title{
O FILOZOFICZNYCH ŹRÓDŁACH RACJONALNOŚCI KOMUNIKACYJNEJ \\ - CZYLI W STRONĘ HERMENEUTYCZNEJ INTERPRETACJI TEORII HABERMASA
}

Rafał Wonicki

Uniwersytet Warszawski, Polska Akademia Nauk

/// Tomasz Maślanka. Racjonalność i komunikacja. Filozoficzne podstawy teorii spotecznej Jürgena Habermasa

Dzisiaj mało kto wierzy jeszcze w rozum oświeceniowy, raczej służy on antyoświeceniu, a słowo racjonalność może brzmieć dla wielu pejoratywnie - nastąpił bowiem zmierzch oświecenia, a światło rozumu, które chciało szerzyć kulturę racjonalną, straciło swoją moc. Nastapił zwrot ku temu, o czym w imię rozumu zapomniano, ku temu, co rozumowi obce, co „inne” wobec niego. Zaczęło się też rozum podejrzewać o ideologię, o przymierze z panowaniem i techniczno-przemysłowym niszczeniem przyrody. Wielu myślicieli uznało, że przyrody i wolności należy bronić przed racjonalnością, którą mieszczański ruch oświeceniowy uważał za naturalnego sprzymierzeńca. Dodatkowo kryzys racjonalności potęguje zarzut imperializmu czy totalitaryzmu, podając, że mieszczańskie oświecenie, szerząc racjonalizm w imię wolności i zrównania ludzi wobec prawa, doprowadziło do dehumanizacji wartości i człowieka.

Jürgen Habermas, którego koncepcja jest głównym tematem recenzowanej pozycji, przeciwstawia się powyższej diagnozie postmodernistycznej. Jednym z jego celów jest chęć pokazania, że nie możemy rezygnować $\mathrm{z}$ pojęcia racjonalności. Aby jednak bronić rozumu, musimy dysponować przekonująca jego teorią - taką, która pozwala na odrzucenie powyższych zarzutów. Habermas stworzył taką pojemną teorię racjonalności, wykorzystująca najnowsze osiągnięcia z różnych dziedzin filozofii i socjologii, co pozwoliło mu odnowić klasyczną filozofię praktyczną w czasach współczesnych. 
Celem książki, jak deklaruje autor, jest właśnie wskazanie podstaw, na których wspiera się teoria działania komunikacyjnego Habermasa. Aby to osiagnąć, Tomasz Maślanka rekonstruuje najpierw wczesne próby Habermasa, uznając, że najważniejszą kategoria jest pojęcie ustrukturyzowanej komunikacyjnej sfery publicznej, a także wskazuje na zakończone niepowiedzeniem wysiłki Habermasa $z$ Erkenntnis und Interesse oparcia krytycznej teorii społecznej na epistemologii. Kolejnym etapem jest porównanie stanowiska Habermasa z filozofią Hansa Georga Gadamera i teoria systemów Niklasa Luhmanna oraz rekonstrukcja najważniejszych elementów Teorii działania komunikacyjnego (dalej TDK).

W tym miejscu warto nadmienić, że recenzja ta jest więc skierowana przede wszystkich do szerszego grona czytelników, którzy chcieliby wyrobić sobie zdanie, czy warto czytać teorię autora będąca głównym tematem książki. Piszącemu chodzi zatem o wskazanie głównych wątków, jakie zostały zaprezentowane w recenzowanej pracy, by pokazać jednocześnie wartość i aktualność teorii samego Habermasa.

Zacznijmy jednak od spraw formalnych. Książka ma jasną i czytelną strukturę. Jest podzielona na logicznie uzupełniające się części, które powoduja, że czytelnik otrzymuje dobrze zanalizowany i syntetycznie zaprezentowany materiał, a dzięki precyzji języka stosowanego przez Maślankę materiał ten zyskuje dodatkowo na klarowności. Książka nie zasługuje tym samym na zarzut - który często jest wysuwany pod adresem samego Habermasa - dotyczący piętrowej architektoniki wywodu i szczegółowości polemiki, a także akademickości stylu, który nie sprzyja łatwemu zrozumieniu tekstu. Praca Maślanki nie poddaje się tego typu krytyce. Można za to zadać pytanie o to, czy rekonstruując wywody i polemiki Habermasa, należy podążać za jego językiem, czy starać się od niego oderwać. Gdy będziemy odtwarzać język Habermasa, możemy nie rozhermetyzować jego treści i celów, gdy zaś zbytnio oderwiemy się od języka rekonstruowanej teorii, to grozi nam ideologiczna mistyfikacja albo mylna interpretacja. W tym wypadku Maślanka jest życzliwym interpretatorem, który stara się podążać za intencjami twórcy Teorii dżiałania komunikacyjnego, posługując się najważniejszymi, kluczowymi pojęciami Habermasa, ale wyjaśniając je również bez „habermasowskiego żargonu”, co tylko uwypukla zalety pracy.

Przechodząc do oceny zawartości merytorycznej, wybierzemy drogę pośrednią między streszczeniem wątków głównych a polemiką, by wskazać mocne i słabe, naszym zdaniem, strony pracy. W rozdziale pierwszym i drugim autor rekonstruuje wątki, które umożliwiają prześledzenie, 
w jaki sposób Habermas próbował osadzić teorię społeczną w epistemologii i z powodu jakich trudności wycofał się z tego pomysłu. Rozważania te dokonywane są na podstawie dwóch prac: Erkenntnis und Interesse oraz Strukturwandel der Öffentlichkeit. W tej drugiej pracy Habermas, opisując sferę publiczną i jej przeobrażenia, ma na celu krytykę demokracji formalnej i tej jej cechy, którą jest odpolitycznienie obywateli. Aby mogli oni w wolny od przemocy sposób kształtować swoje decyzje, muszą rozpoznać swoja sytuację w społeczeństwie. Tak oto w sferze publicznej taki porządek panowania, który chce być prawowity, musi być zarazem rozumny, jak i dyskursywny, a więc wolny od przemocy. Wolny zaś może być jedynie wtedy, gdy podmioty w społeczeństwie będą realizowały interes emancypacyjny - interes będący poznaniem i rozpoznaniem przemocy. Sfera publiczna jest więc związana w teorii Habermasa z racjonalnością nieinstrumentalną. Pełni ona funkcję legitymizująca porządek społeczny. Jednocześnie Habermas - aby wskazać na istotna rolę sfery publicznej - historycznie rekonstruuje proces jej przemiany. Jak pisze Maślanka, „[p]rzestaje ona być obszarem dyskursywnego kształtowania i wyrażania woli powszechnej, służąc w coraz większym stopniu realizacji pewnego apriorycznego wzorca życia społecznego" ${ }^{1}$. Jest to wyrazem powstania świadomości technokratycznej, dominacji sfery ekonomii w społeczeństwie. Doprowadza do zaniku legitymizacji przez komunikację i wzrostu systemowej racjonalności techniczno-naukowej. Emancypacyjny potencjał sfery publicznej ulega zapomnieniu. Niemniej jednak, zdaniem Habermasa, jedynie dyskusja nad normami postępowania obowiązującymi we wspólnocie może odblokować potencjał emancypacyjny. W Erkenntnis und Interesse, polemizując choćby z Charlesem Peircem i Wilhelmem Diltheyem, dowodzi, że poznanie rządzi się zawsze jakimś interesem, wyróżniając oprócz nauk analityczno-empirycznych i hermeneutyczno-historycznych nauki krytyczne, które kieruja się interesem emancypacyjnym i maja w sferze publicznej pomagać w uzyskaniu konsensusu.

Największym dyskutantem i inspiracja przy obronie interesu emancypacyjnego staje się zarazem Gadamer ze swoja postheideggerowską hermeneutyką. Należy podkreślić, że Maślanka wnikliwie opisał wciąż mało dyskutowaną na polskim gruncie debatę między Gadamerem a Habermasem, dokonując analizy porównawczej w ich podejściu do rozumienia tego, czym jest język i jakie funkcje pełni ${ }^{2}$. Nie wnikając w szczegóły, Habermas

\footnotetext{
${ }^{1}$ Maślanka, Tomasz. Racjonalność i komunikacja. Filozoficzne podstany teorii spotecznej Jürgena Habermasa. Warszawa: Wydawnictwa Uniwersytetu Warszawskiego, 2011, s. 33.

${ }^{2}$ Tamże, s. 50-73.
} 
zgodził się z Gadamerem, jeśli chodzi o ważność roli przesądów w naszym sposobie myślenia i działania. Jego głównym zarzutem było jednak twierdzenie, że Gadamer, rehabilitując przesądy, odrzuca myśl oświeceniową oraz uznaje bezkrytycznie moc konserwatywnej tradycji i autorytetu. Gadamer w swojej odpowiedzi na zarzuty wskazał między innymi na mylne rozumienie przez Habermasa niektórych jego sformułowań dotyczących celów hermeneutyki oraz tego, czym ona jest. Habermas twierdził również - choć później pod wpływem repliki Gadamera się z tego wycofał - że dobrym przykładem nauk emancypacyjnych jest psychologia jako krytyka społeczna. Gadamer i w tym przypadku uznał, że Habermas się myli. Psychoanaliza nie jest hermeneutyka, ponieważ obie strony nie są w niej równoprawne, a rozszerzenie mechanizmu psychoanalizy na krytykę społeczna prowadziłoby prosto w objęcia dogmatyzmu. Na dyskusji z Gadamerem Habermas mimo wszystko zyskał, akceptując fakt, że nie ma pozycji uprzywilejowanej, obiektywnej, którą postulował, rozwijając pojęcie interesu emancypacyjnego. Krytykując Gadamera za zajęcie przez hermeneutykę takiej pozycji z perspektywy teorii krytycznej, sam popadł w ideologizację, którą chciał przezwyciężyć. Rezygnując z psychoanalizy jako metody paradygmatycznej do rozumienia stosunków społecznych, Habermas uznał więc słuszność krytyki Gadamera. Między innymi pod wpływem powyższej polemiki Habermas dokonal zwrotu lingwistycznego w swojej koncepcji i zaczął szukać możliwości likwidacji źródeł przymusu w sferze publicznej, budując teorię działania komunikacyjnego, do której opisu teraz przejdziemy.

Najbardziej newralgiczne momenty TDK Maślanka rekonstruuje w swojej pracy w rozdziale trzecim ${ }^{3}$. Rozdział ten jest największy i zajmuje prawie połowę pracy, co tworzy lekka dysproporcję w harmonii, ale dysproporcje dająca się uzasadnić przyjęta na początku strategia badawczą autora oraz wielkością, wielością i ważnością wątków poruszanych w TDK.

Jednym z podstawowych celów TDK jest stworzenie teorii racjonalności komunikacyjnej, na tyle szerokiej, by objąć zarówno paradygmat systemowy, jak i paradygmat świata życia w naukach społecznych. W tym miejscu znów wydaje się, że ważniejsze niż szczegółowa relacja z wywodów Maślanki dotycząca analiz i polemik zawartych w TDK jest zachęcenie czytelnika, niezaznajomionego z teorią Habermasa, do sięgnięcia przynajmniej po recenzowana pozycję jako dobry wstęp do filozofii społecznej Habermasa. W tym celu skupimy się jedynie na rekonstrukcji

${ }^{3}$ Tamże, s. 97-191. 
kluczowych filozoficznych elementów w teorii Habermasa, zaczynając od opisu działania komunikacyjnego oraz relacji między światem życia a systemem.

Tworzac teorię działania komunikacyjnego, Habermas wychodzi z założenia, że „w gramatyce języka zawarte są już potencjalne reguły uspołecznienia, a samo rozumienie języka jest powtórzeniem procesu socjalizacji” " Uznaje on zatem, że w samym języku zawarte są reguły rozumienia i porozumienia. Język staje się intersubiektywnym medium, dzięki któremu strony w działaniu komunikacyjnym moga weryfikować swoje roszczenia (do prawdziwości, szczerości lub normatywnej słuszności). Teoria działania komunikacyjnego jest więc dla Habermasa teorią racjonalności. Jak mówi autor: „Wyrażając chęć porozumienia się co do czegoś w świecie, musimy przyjąć pewien wspólny horyzont sensu" ${ }^{5}$. Język bowiem jest umieszczony w świecie życia (w horyzoncie sensu), komunikując się zatem z innymi, zgłaszamy różnego rodzaju roszczenia ważnościowe co do świata zewnętrznego, wewnętrznego i społecznego. Roszczenia te możemy poddawać krytyce, czyli odróżniać racjonalne roszczenia od nieracjonalnych i zajmować wobec nich stanowisko na tak lub nie.

W konsekwencji oznacza to taką koncepcję, w której wszelkie twierdzenia czy też akty mowy uzyskuja moc wiążąca dzięki roszczeniom ważnościowym (uzyskujemy też gwarancję, że same te roszczenia moga być poddane krytyce, co umożliwia ich weryfikację za pomocą argumentów). Taka konstrukcja teorii racjonalności komunikacyjnej powiązanej z analizami z zakresu filozofii języka (teorii aktów mowy Johna L. Austina czy Johna R. Searle’a) pozwala Habermasowi ustalić związki między znaczeniem i ważnością. Opis tych związków Habermas nazywa uniwersalna pragmatyka. Ma ona za zadanie ustalić ogólne przesłanki działania komunikacyjnego oraz zrekonstruować kompetencję komunikacyjna podmiotów, wiążąc akty mowy z ich odniesieniami.

Uniwersalna pragmatyka, składająca się zatem z teorii aktów mowy i kompetencji komunikacyjnej, wskazuje na istnienie dwu form komunikacji. Jedną jest dzৃiałanie komunikacyjne, które zakłada akceptację roszczeń zawartych implicite $\mathrm{w}$ wypowiedziach, a druga dyskurs, który tematyzuje te roszczenia ważnościowe, co do których nie ma pierwotnej zgody. Działanie komunikacyjne jest nakierowane na osiagnięcie porozumienia, w przeciwieństwie do innych typów działań, np. instrumentalnych czy strategicznych, zorientowanych na osiagnięcie konkretnego rezultatu.

\footnotetext{
${ }^{4}$ Tamże, s. 47

${ }^{5}$ Tamże, s. 88.
} 
Dyskurs z kolei zakłada przyjęcie idealnej sytuacji komunikacyjnej umożliwiającej prowadzenie sporów dotyczących prawdziwości określonych faktów (dyskurs teoretyczny) czy słuszności określonych norm (dyskurs praktyczny). Natomiast idealna sytuacja komunikacyjna opisuje ogólne warunki, które każdy użytkownik języka musi założyć, o ile chce argumentować. Jej przyjęcie pozwala na problematyzowanie kwestii dotyczących normatywnej słuszności, na ich racjonalne argumentowanie i rozwiązywanie sporów za pomocą odpowiedniej procedury. Ma ona służyć weryfikowaniu poszczególnych elementów świata przeżywanego i uniwersalizowaniu tych z nich, które uzyskały powszechne uznanie, stając się w ten sposób normami. W idealnej sytuacji komunikacyjnej wykluczony zostaje również wszelki przymus, poza przymusem lepszego argumentu.

Zajmijmy się teraz pokazaniem, jak Habermas na bazie teorii działania komunikacyjnego dokonuje połączenia dwóch podejść w socjologii, tworząc ich syntezę - podejścia systemowego i rozumiejącego (świat życia). Zacznijmy od systemu. Jeśli chodzi o system, to jest on przez Habermasa definiowany jako przestrzeń, w której integracja dokonuje się przez funkcjonalne splątanie ze sobą następstw działania. System składa się z dwóch głównych podsystemów, którymi są rynek z medium pieniądza i państwo z medium władzy. Krytykę podejścia systemowego dotyczącą opisu problemów świata społecznego otrzymujemy dzięki rekonstrukcji przez Maślankę drugiej słynnej polemiki - polemiki Habermasa z Luhmannem. Znów, tak jak wcześniej, nie będziemy szczegółowo zdawali relacji z przebiegu tej polemiki i skupimy się na jej wyniku. Teoria Luhmanna, tak jak inne podejścia systemowe, jest użyteczna w analizie mechanizmów integracji systemowej, ale nie może stosować się do wszystkich sfer integracji społecznej. Dodatkowa trudność dla Habermasa w przypadku Luhmanna stanowi fakt, że nie wiadomo, gdzie w jego teorii kończy się system, a zaczyna środowisko ${ }^{6}$. Wynikiem krytycznej analizy teorii Luhmanna jest konstatacja, że teorie systemowo-funkcjonalne nie dysponuja dobrymi procedurami badawczymi, by stanowić podstawę nauk społecznych o intencjach praktycznych. Muszą one być więc uzupełnione o wymiar hermeneutyczno-historyczny (streszczona wcześniej polemika z Gadamerem). Zdaniem Habermasa bowiem teoria Luhmanna, rezygnując z kryteriów normatywnych, nie będzie w stanie wyłowić ideologicznych zniekształceń komunikacji. Niemniej jednak, widząc zalety teorii systemów w opisywaniu tych obszarów życia społecznego, z którymi nie radzą sobie teorie działania, Habermas buduje teorię łącząca świat

${ }^{6}$ Tamże, s. 77. 
życia i system. Przejdźmy zatem do opisu tego, jak Habermas rozumie świat życia.

Świat życia, jak mówi Maślanka „[...] nie jest już pojmowany przez Habermasa na modłę fenomenologiczną jako korelat aktów świadomości, lecz jako nie do końca uświadamiany zasób wiedzy kulturowej o charakterze intersubiektywnym" ". Przekaz kulturowy zatem nie może być dogmatyczny, jego zadaniem jest bowiem umożliwienie nam samorefleksji. Musi umożliwić nam oddzielenie działań celowych od działań komunikacyjnych, w których aktorzy starają się dojść do porozumienia w celu koordynacji wspólnych działań. Świat życia stanowi więc zasób możliwych interpretacji, rozstrzygając o sensowności wypowiedzi. Pozostaje on w tle komunikacji, umożliwiając ja. Mówiąc inaczej, rozum komunikacyjny jest osadzony w kulturowej przestrzeni społecznej. Podstawą działania komunikacyjnego staje się więc porozumienie dokonujące się $\mathrm{w}$ medium języka. Z kolei język jako nośnik sensów zakorzeniony jest w świecie życia. Habermas zalicza do świata życia, oprócz kultury, także struktury osobowości i społeczeństwa. Pozwala mu to na pokazanie, że działanie komunikacyjne służy również procesom potwierdzania, odnawiania, przekazywania i kształtowania tożsamości jednostkowych (socjalizacja) i zbiorowych (integracja społeczna). Procesy te stanowia podstawę integracji społeczno-politycznej. Jest tak dlatego, że udane procesy reprodukcji kulturowej oraz integracji społecznej stanowią źródło społecznie uznanych uprawomocnień istniejącego porządku normatywno-instytucjonalnego.

Maślanka śledzi, jak Habermas dowodzi prawomocności wyżej opisanej struktury, rekonstruując za nim, po pierwsze, powszechne reguły rządzące czynnościami mowy (dyskusja z Austinem i jego perlokucyjna i illokucyjna funkcja języka); po drugie, wydobywając patologie komunikacyjne, by ustalić normy komunikacyjne, i, po trzecie, odtwarzając Habermasowską krytykę teorii racjonalności społecznej Maxa Webera. Cząstkową analizę pierwszego punktu przedstawiliśmy przy opisie uniwersalnej pragmatyki, dyskursu i działania komunikacyjnego, teraz więc zatrzymamy się na dłużej przy Weberze jako teoretyku nowożytnej racjonalności społecznej i przy Habermasa identyfikacji patologii społecznych.

Habermasa interesuje w teorii Webera przede wszystkim kwestia przyjęcia przez niego zbyt wąskiego pojęcia racjonalności celowościowej użytej do badania systemów działania ${ }^{8}$. Co więcej, Weber utożsamia racjonalność społeczna z procesem kapitalistycznej modernizacji i biurokratyzacji, co

\footnotetext{
${ }^{7}$ Tamże, s. 95.

${ }^{8}$ Tamże, s. 131.
} 
dla Habermasa jest równoznaczne z odrzuceniem racjonalności komunikacyjnej i uznaniem, że racjonalność instrumentalna (ze sfery ekonomii) staje się również modelem racjonalności politycznej. Dla Habermasa zaś „[r]acjonalność instytucji społeczeństwa obywatelskiego może dokonać się tylko w jeden sposób - za pomoca wolnej od przemocy dyskusji nad społecznie obowiązującymi normami" 9. Mimo wszystko upatruje on w teorii Webera najlepsze narzędzie mogące wyjaśnić patologie życia społecznego. Patologie te spowodowane są niesymetrycznością między światem życia a systemem (zanik sprzężenia między integracją społeczna a integracją systemowa prowadzi do urzeczowienia). TDK ma zatem nie tylko diagnozować kondycję nowożytnej wspólnoty politycznej, ale wskazać na możliwe sposoby naprawy tej sytuacji, np. przez konieczność dowartościowania sfery publicznej. Działanie komunikacyjne służy bowiem porozumieniu, czyli odnawianiu de facto wiedzy kulturowej, potwierdzaniu norm, integrowaniu wspólnoty politycznej oraz kształtowaniu jednostkowej tożsamości. Dobra teoria społeczna powinna dotyczyć więc reprodukcji kulturowej, socjalizacji i integracji społecznej (świat życia) oraz reprodukcji systemowej (rynek, polityka, prawo). Powinna też wskazywać i tłumaczyć występujące zaburzenia w tych obszarach. Habermas identyfikuje przynajmniej trzy grupy zaburzeń i ich efekty. Zaburzenia reprodukcji kulturowej powoduja poczucie utraty sensu, podmioty maja trudności z porozumieniem się. Oznaką zakłóceń jest również utrata przez wiedzę kulturowa jej racjonalności rozumianej w kategoriach ciagłości i spójności oraz zanik prawomocności (Gültigkeit) istniejącego porządku społecznego. Gdy zostaje zaburzony proces integracji społecznej, dochodzi do anomii i wyobcowania, czyli do zmniejszenia stopnia uprawomocnienia istniejacych stosunków społecznych. Rezultatem zaś nieprawidłowości w procesie socjalizacji jest wzrost psychopatologii prowadzacej do zerwania tradycji kulturowej i utraty motywacji do działania ${ }^{10}$. Bardzo ogólnie wszystkie te zaburzenia związane sa z tym, co Habermas nazywa kolonizacja świata życia przez system rynku z medium pieniądza i system polityki z medium władzy.

Kolonizacja przyjmuje też postać jurydyzacji, czyli przyrostu prawa pisanego. Zaczyna ono być rozumiane jako medium uspołecznienia i integracji społecznej. Z punktu widzenia rehabilitacji sfery politycznej jako komunikacyjnej sfery publicznej prawo, przejmując rolę medium sterowania w sferze politycznej, sprowadza się do wzrostu administrowania, co zaburza

\footnotetext{
${ }^{9}$ Tamże, s. 115.

${ }^{10}$ Tamże, s. 163.
} 
proces wytwarzania normatywnego konsensusu, czyli możliwość kwestionowania przyjmowanych przez władzę celów i metod osiagania tych wyników. A jak zakłada Habermas, w politycznej sferze publicznej obywatelskie uczestnictwo jest warunkiem sine qua non komunikacyjnej legitymizacji decyzji politycznych. Brak uczestnictwa równa się więc brakowi legitymizacji oraz kolonizacji świata życia przez system. Choć bowiem obywatelom wydaje się, że sfera systemowa jest niezależna od świata życia, to okazuje się, iż jest z nim powiązana, ponieważ mechanizmy systemowe nie mogłyby utrwalić się w społeczeństwie, gdyby nie były zakorzenione w świecie życia. Zostają one zaakceptowane tylko wtedy, gdy struktury świata życia na danym etapie rozwoju sa dostatecznie zracjonalizowane. Odpowiedni poziom rozwoju muszą osiagnąć zwłaszcza prawo i moralność, które czerpią swoją legitymizację (Legitimation) ze świata życia. Ewolucja systemowa jest więc akceptowana, jeśli poziom prawa i moralności jest wystarczający, by społeczeństwo poradziło sobie z niebezpieczeństwami wynikającymi z tej modernizacji. Rolą prawa i moralności jest zatem zapobieganie otwartym konfliktom, które moga zagrozić owej integracji. Kluczowym elementem w tej diagnozie jest pokazanie, że podtrzymanie porządku społecznego oraz transmisja wiedzy i wartości nie może istnieć bez odwołania się do wspólnych założeń w kwestii świata zewnętrznego oraz roszczeń do prawdy czy słuszności, które Habermas nazywa kontrfaktyczną idealizacja. Jest ona źródłem napięcia między faktycznością (tym, jak jest) a ważnością (Geltung), czyli tym, jak być powinno. Habermas analizuje zatem, w jaki sposób w sferze społeczno-politycznej moment ważności i faktyczności łączą się w całość. Jego zdaniem współcześnie społeczeństwa pod wpływem sekularyzacji oraz pluralizmu nie musza już polegać na tradycji i silnych instytucjach (np. religii), by budować pomost między faktycznością a ważnością. Po to, by sprostać zadaniu społecznej reprodukcji i integracji, powinny one zwrócić się w innym kierunku i przestać odwoływać się do tradycji. Rolę taką przejmuje w systemie Habermasa, w toku ewolucji jego poglądów, prawo i demokracja (dyskurs praktyczny w wymiarze politycznym).

W TDK dzięki połączeniu w paradygmacie lingwistycznym perspektywy systemowej (pozytywistyczne nauki społeczne) oraz perspektywy nauk rozumiejących (hermeneutyka Gadamera) udaje się zatem Habermasowi zrealizować idee pierwszej teorii krytycznej, czyli pogodzić wymóg naukowości i obiektywności z filozofia praktyczną. Maślanka słusznie wskazuje, za Habermasem, na chęć przezwyciężenia aporii, w które popadła „stara” teoria krytyczna Horkheimera i Adorno, związanych 
z nieprzekroczeniem przez nią paradygmatu filozofii świadomości. Ponieważ wątek ten jest zmarginalizowany w książce, a wydaje się ważny dla zrozumienia teorii Habermasa, przypomnijmy go w tym miejscu. Możemy powiedzieć, że mankamentem teorii krytycznej dla Habermasa był właśnie jej deficyt polityczny, ponieważ wersja Horkheimera i Adorno zrezygnowała w latach 40. XX w. z zamiaru oddziaływania na rzeczywistość polityczną i społeczna, wraz z uświadomieniem sobie przez nich nieistnienia rewolucyjnego podmiotu przemian. Wiązało się to również ze zwątpieniem $\mathrm{w}$ urzeczywistnienie się $\mathrm{w}$ wymiarze społecznym rozumu, który ich zdaniem nie pełnił już funkcji emancypacyjnej, a był raczej narzędziem zniewolenia. Habermas nie zgadza się z taką diagnoza, gdyż wierzy, że są takie sfery życia społecznego, które nie sa zniewolone. By przywrócić jedność teorii i praktyce, skupia się na samej teorii, która musi być świadoma swojej relacji wobec praktyki. Musi być to zatem refleksyjna teoria krytyczna. Warunek ten przewodzi myśli Habermasa w całej jego twórczości, od historycznej rekonstrukcji sposobów ujmowania polityki zawartej w Teorii $i$ praktyce po teorię racjonalności komunikacyjnej przedstawiona $\mathrm{w}$ Teorii działania komunikacyjnego.

Ostatnie partie książki poświęcone są krytyce teorii Habermasa i dotyczą takich rzeczy, jak status racjonalności komunikacyjnej i tego choćby, że Habermas nie uzasadnił należycie tezy, iż język zorientowany jest na porozumienie (Karl Otto Apel, McCarthy). Maślanka wskazuje na słabe punkty teorii działania komunikacyjnego, pokazując na przykład, że Habermas ma kłopot $z$ pogodzeniem formalnych procedur dyskusji z ich historyczną ewolucją. Oddzielnie i trochę z boku potraktowany jest problem prawdy i podmiotu, który zostaje omówiony osobno w rozdziale czwartym, niejako wydobywającym dodatkowe filozoficzne akcenty z teorii Habermasa (np. teorię prawdy konsensualnej), służące, jak się wydaje, podkreśleniu, że dochodzenie do porozumienia jest dochodzeniem do prawdy, a więc jest związane $z$ intersubiektywnie zapewnianą ważnością sądów ${ }^{11}$. Wybór ten wskazuje na interpretację Habermasa oczami hermeneuty. Choć są to kategorie dla filozofii ważne, to wydaje się, że inne kategorie są równie ważne i uznane za takie także przez samego Habermasa, np. praca i interakcja. Ich bardziej pogłębiona analiza, jako filozoficznych podstaw socjologicznej teorii Habermasa, byłaby w książce przydatna, choć sam autor ma świadomość, że z bogatej i wielowątkowej refleksji Habermasa należało coś wybrać. Wybór ten pozwolił wręcz opisać wybrane wątki jako pewien całościowy projekt zmierzający do wspólnego celu. Rekonstrukcja

${ }^{11}$ Tamże, s. 196. 
stała się tym samym interpretacja, a zasada wyboru wpłynęła na porządkowanie i rozumienie opisywanego materiału. Niemniej jednak należy zadać sobie pytanie dotyczące zasadności wyboru i rekonstrukcji z określonej perspektywy dzieł Habermasa. Strukturwandel der Öffentlichkeit, od której opisu zaczyna Maślanka, jest pierwszą znaną i ważną jego praca. Zatem jeśli bierzemy ją za punkt odniesienia i przez pryzmat problemów, do jakich się ona odnosi, ustawiamy naszą optykę interpretacyjną, to czy nie powinniśmy bardziej uwypuklić, oprócz Erkenntnis und Interesse oraz Theorie des kommunikativen Handelns, przynajmniej dwóch innych prac: Theorie und Praxis (gdzie Habermas mierzy się z problemem statusu nauk socjologicznych, relacją teorii i praktyki, metoda krytyczną oraz relacja pracy i interakcji) oraz Faktizität und Geltung, w której Habermas doprecyzowuje swoje wywody dotyczące dyskursu, działania komunikacyjnego i sfery polityki jako par excellence sfery praktyki, zmieniając zarazem nieco swe rozumienie sfery publicznej oraz podejście do roli prawa? Z kolei uwypuklenie wątków hermeneutycznych i przekroczenia dwóch paradygmatów w filozofii społecznej i socjologii (świata życia i systemu) wskazywałoby na umieszczenie rozważań autora w trochę innym polu odniesień filozoficznych, czyli w obszarze filozofii społecznej i filozofii kultury. Wtedy książka domaga się uzupełnienia o inne ważne prace Habermasa, takie jak choćby Kultur und Kritik. Wydaje się, że oba podejścia występują w pracy, a ponieważ piszący recenzję sprzyja bardziej pierwszemu pomysłowi, to zabrakło mu większej liczby odniesień do sfery publicznej i prawa. Warto więc, korzystając z okazji, podkreślić, że w oczach Habermasa idea „opinii publicznej” jest nowym typem uprawomocnienia porządku politycznego i społecznego występującego w nowoczesnych społeczeństwach. Jest to dla niego najbardziej adekwatny model przystający do obecnych warunków, w przeciwieństwie do modelu decyzjonistycznego i technokratycznego, które skrytykował jako nieprzystające do wymogów sytuacji społecznej i uniemożliwiające realizację politycznego oświecenia. Wiąże się to również z nowym typem uprawomocnienia proceduralnego. Jak mówi Habermas w Legitimationsprobleme im Spätkapitalismus, „,...] ponieważ nie można już teoretycznie uwiarygodnić ostatecznych racji, legitymizująca moc uzyskują same formalne warunki uzasadniania. Procedury i przesłanki rozumnego osiagania zgody same stają się ostateczną zasadą" ${ }^{12}$. Oznacza to, że głównym współcześnie uprawomocnieniem są reguły komunikacji, które pozwalają odróżnić

${ }^{12}$ Cyt. za: tamże, s. 277. 
porozumienie wolnych obywateli i porozumienie wymuszone, uprawomocnieniem bowiem jest tu praktyczne materialne porozumienie wyrażające wspólną i świadomą wolę obywateli. Ten typ uprawomocnienia wyraża się właśnie w idei opinii publicznej. Sama teoria rozumie siebie tu więc jako część praktyki społeczno-politycznego rozwoju. Nastawiona jest zatem na praktyczną orientację rozwoju wspólnotowego, czyli również na realizację pewnego porządku etyczno-prawnego.

W związku z tym, że autor pod koniec pracy świetnie pokazuje słabości i ewentualne trudności teorii Habermasa, wypada w tym miejscu wskazać tylko na niektóre zalety propozycji Habermasa, niewydobyte w pracy Maślanki z perspektywy filozofii polityki. Habermas broni oświecenia i „niedokończonego" projektu oświeceniowego przed jego krytykami, przed konserwatystami, komunitarianami, a nawet myślicielami lewicowymi oskarżającymi rozum oświeceniowy o tendencje totalizujące i alienujące. Stara się on wypracować nową formułę oświecenia i obronić rozum. Udaje mu się to właśnie dzięki stworzeniu szerokiej koncepcji racjonalności komunikacyjnej. Racjonalności, która nie jest ani substancjalna, ani instrumentalna. Jest to racjonalność dotycząca wszystkich działań odbywających się w obrębie interpersonalnych relacji między ludźmi. Taka formuła racjonalności odsyła nas do pojęcia wolności jako wzajemnego uznania autonomii równych podmiotów działania. Działanie komunikacyjne jest działaniem autotelicznym w medium języka. Dopiero więc w ramach działania komunikacyjnego możemy doświadczyć wolności - wolności objawiającej się wspólnym dochodzeniem do porozumienia, porozumieniem osiaganym na drodze dyskusji. Działanie komunikacyjne zasadza się więc na uznaniu w punkcie wyjścia równości i wolności wszystkich podmiotów biorących w niej udział. Aby jednostki faktycznie cieszyły się swoją wolnością i równością w życiu społecznym, muszą zostać rozpoznane i wyeliminowane wszelkie formy przemocy. Jednym ze sposobów eliminacji przemocy jest uznanie możliwości krytyki wszelkich roszczeń. To dopiero swobodna wymiana argumentów zainteresowanych stron, bez z góry narzuconego rezultatu związanego ze stosunkami panowania, powinna umożliwiać konsensus. Mechanizm ten sprzyja również uczeniu się na własnych błędach. Taka optyka wskazuje na słuszność opisywania przez Maślankę rozumu komunikacyjnego jako rozumu historycznego. Racjonalność bowiem nie jest zastanym faktem, czymś niezmiennym, ale dziejowym procesem. Intuicja ta jest bliska intuicji Heglowskiej związanej z rozwojem wolności. Dla Habermasa rozwój ten, a więc i zwiększenie się sfery racjonalności komunikacyjnej, dokonuje się, 
gdy coraz więcej sfer społecznych poddanych jest kontroli demokratycznej. W tym sensie Habermas nie jest tylko socjologiem-metodologiem wypracowującym nową adekwatna teorię opisu coraz bardziej złożonego życia społecznego, ale również filozofem wierzącym w postęp i emancypację. Emancypacja ta (minimalistycznie, a więc i antymarksowsko) nie wiąże się z żadnym przewrotem rewolucyjnym, ale z konsekwentnym usuwaniem barier w komunikacji wewnątrz wspólnoty politycznej. Największe zagrożenie, jakie upatruje Habermas, to właśnie przenikanie racjonalności instrumentalnej do sfery interakcji komunikacyjnej.

Podsumowując, należy powiedzieć, ̇̇e najważniejszymi zaletami tej pracy jest rekonstrukcja filozoficznych źródeł racjonalności komunikacyjnej oraz wykazanie podobieństwa między teorią działania komunikacyjnego a hermeneutyką Gadamera. Cel książki i zamysł autora, którym było prześledzenie rozwoju myśli Habermasa oraz pokazanie, jak socjologiczna teoria działania przez niego wypracowania jest zarazem filozoficzna teorią racjonalności, należy uznać więc za w pełni zrealizowany. 